\title{
BRIP1 Gene Mutation Negative
}

National Cancer Institute

\section{Source}

National Cancer Institute. BRIP1 Gene Mutation Negative. NCI Thesaurus. Code C159780.

A genetic finding indicating that BRIP1 gene mutations have not been detected in a sample. 